\title{
Pengembangan Program Pembelajaran Tahsin di Lembaga Semi Otonom Qur'an Institute UNJ
}

\author{
Sulistiyo Handayani, ${ }^{1 \varpi}$ Dewi Salma Prawiradilaga ${ }^{2}$, Suprayekti ${ }^{2}$ \\ ${ }^{1}$ Universitas Negeri Jakarta, Jakarta, Indonesia. \\ ${ }^{2}$ Universitas Negeri Jakarta, Jakarta, Indonesia. \\ 3 Universitas Negeri Jakarta, Jakarta, Indonesia.
}

DOI: https://doi.org/10.21009/JPI.o41.03

\begin{tabular}{|c|c|}
\hline le History & trak \\
\hline $\begin{array}{l}\text { Development; } \\
\text { Instructional Program; } \\
\text { Tahseen Al-Qur'an; } \\
\text { Instructional } \\
\text { Development Model; } \\
\text { MPI. }\end{array}$ & $\begin{array}{l}\text { Penelitian pengembangan ini dilakukan, karena program pembelajaran tahsin yang } \\
\text { dimiliki pada Lembaga Semi Otonom (LSO) Qur'an Institute belum terstruktur. } \\
\text { Adapun tujuan penelitian ini adalah untuk menghasilkan program pembelajaran } \\
\text { tahsin Al-Qur'an untuk pembelajaran tahsin level 1. Penelitian pengembangan ini } \\
\text { dilakukan berdasarkan Model Pengembangan Instruksional (MPI) dari Prof. Atwi } \\
\text { Suparman yang memiliki delapan tahapan. Evaluasi formatif yang dilakukan dalam } \\
\text { penelitian ini ialah expert review dan one to one, dengan melibatkan ahli desain } \\
\text { pembelajaran, ahli materi, pengajar dan peserta SQI. Perolehan nilai rata-rata dari } \\
\text { expert review oleh ahli desain pembelajaran adalah 3,13 yang menunjukkan kriteria } \\
\text { baik. Pada ahli materi diperoleh rata-rata 3,72 dengan kriteria sangat baik. Sedangkan } \\
\text { pada one to one diperoleh rata-rata 3,30 dengan kriteria sangat baik. Dari hasil } \\
\text { evaluasi formatif tersebut maka menunjukkan bahwa program pembelajaran ini baik } \\
\text { dan layak digunakan dalam pembelajaran tahsin Al-Qur'an. }\end{array}$ \\
\hline
\end{tabular}

\begin{abstract}
This research and development was carried out, because the tahseen learning program at Lembaga Semi Otonom (LSO) Qur'an Institute was not yet structured. As for the aims of this research is to produce the instructional program of tahseen Al-Qur'an for tahseen instructional level 1 . This research and development is based on the Instructional Development Model (Model Pengembangan Instruksional / MPI) by Prof. Atwi Suparman that has eight stages. Formative evaluation conducted in this study were expert review and one to one, involving instructional design experts, material experts, instructors, and learners of SQI. The average value of the instructional design expert is 3.13 which showed good criteria. The material experts obtained an average of 3.72 with very good criteria. Whereas one to one obtained an average of 3.30 with very good criteria. From the results of the formative evaluations, it shows that this instructional program is good and worthy to be used in the Tahseen Qur'an instructional.
\end{abstract}

\footnotetext{
$\bowtie$ Corresponding author : Sulistiyo Handayani Alamat : Universita Negeri Jakarta

Jakarta, Indonesia

E-mail : sulistiyo.handayani97@gmail.com 


\section{PENDAHULUAN}

Pendidikan mendukung perkembangan pada berbagai bidang, seperti ekonomi, sosial, politik, seni, budaya, agama, ilmu pengetahuan dan teknologi karena bersifat fundamental. Pendidikan dapat menjadi bekal hidup seseorang untuk meningkatkan kualitas hidupnya di masa mendatang, sekaligus senjata yang dapat mengubah dunia. Sebab itulah, pendidikan memiliki peran yang penting dalam kehidupan manusia.

Pendidikan di Indonesia secara umum dibagi menjadi tiga jalur pendidikan. Setiap jalur pendidikan memiliki ruang lingkupnya masing-masing dalam rangka mencapai tujuan pendidikan nasional. Jalur pendidikan tersebut, terdiri dari jalur formal, informal, dan nonformal. Pendidikan formal dan nonformal merupakan pendidikan yang dapat saling melengkapi.

Sama halnya dengan pendidikan formal, pendidikan nonformal perlu direncanakan sebelum melaksanakannya. Perencanaan ialah langkah yang bersifat prediktif, karena berkaitan dengan penentuan hal yang ingin atau akan dicapai nantinya. Sebuah perencanaan dapat mengantisipasi timbulnya masalah dan memprediksi tingkat keberhasilan. Perencanaan dilakukan tidak hanya pada lingkup pendidikan, akan tetapi juga perlu pada lingkup yang lebih kecil, seperti pembelajaran. Pembelajaran merupakan sub sistem dari pendidikan, sehingga memerlukan perencanaan yang lebih spesifik.

Perencanaan dalam konteks pendidikan dapat diwujudkan sebagai kurikulum. Kurikulum dapat diartikan sebagai sebuah cetak birunya pembelajaran. Sebuah kurikulum yang telah direncanakan dan telah berlaku pada pendidikan tertentu tetap memerlukan pengembangan lebih lanjut. Hal tersebut bertujuan agar kurikulum bersifat dinamis, sehingga dapat menyesuaikan dengan tuntutan zaman dan kondisi masyarakat. Pengembangan kurikulum merupakan kegiatan yang kompleks, karena membutuhkan pengambilan keputusan yang bersifat strategis dan mendasar.

\section{Secara hakikat, pengembangan} kurikulum merupakan pengembangan komponen-komponen kurikulum yang membentuk sistem kurikulum itu sendiri, yaitu komponen tujuan, bahan, metode, peserta didik, media, lingkungan, sumber belajar, dan lain-lain. (Idi, 2011: 208) Jadi, dapat disimpulkan bahwa pengembangan kurikulum merupakan pengembangan pada setiap komponenennya. Komponen inilah yang nantinya menjadi acuan untuk kegiatan pembelajaran. Selain itu, pengembangan kurikulum juga berhubungan dengan penyesuaian terhadap komponen pengaturan standar, penilaian, dan pengembangan program pembelajarannya.

Sedangkan, perencanaan pada lingkup pembelajaran dapat diwujudkan dalam bentuk program pembelajaran. South African Qualifications Authority (SAQA) mendefinisikan program pembelajaran sebagai a learning programme as the sequential learning activities, associated with curriculum implementation, leading to the achievement of a particular qualification or part qualification. In view of the above, the learning programme constitutes the plan for getting the learner to meet the specified outcomes as set out by the curriculum.(SAQA,2015)

Definisi di atas berarti bahwa program pembelajaran sebagai kegiatan belajar yang berurutan, terkait dengan implementasi kurikulum, yang mengutamakan pencapaian kualifikasi atau kualifikasi pada bagian tertentu. Mengingat hal itu, maka program pembelajaran intinya ialah rencana untuk peserta didik agar memenuhi hasil yang telah ditentukan. Jadi, dapat disimpulkan bahwa program pembelajaran merupakan rencana kegiatan belajar yang berurutan untuk 
mencapai hasil atau kualifikasi tertentu dan terkait dengan kurikulum. Dengan demikian, program pembelajaran diantaranya mencakup tujuan, strategi, dan penilaian. Sama halnya dengan kurikulum, sebuah program pembelajaran juga memerlukan pengembangan.

Baik kurikulum maupun program pembelajaran mempunyai kekhususannya masing-masing. Kekhususan dari kurikulum diantaranya yaitu memiliki cakupan yang luas, karena mengacu pada semua kegiatan belajar dan pembelajaran yang ada pada sebuah lembaga, berhubungan dengan pengaturan standar pada lembaga, dan didalamnya terdapat pengembangan program pembelajaran.

Sedangkan kekhususan yang ada pada program pembelajaran diantaranya, yakni memiliki cakupan yang lebih kecil, karena mengacu pada konten pembelajaran tertentu, menekankan pada kegiatan pembelajaran yang terstruktur dengan berbagai sumber, dan pencapaian hasil belajar lebih spesifik.

Adanya program pembelajaran yang didesain secara terencana dan terstruktur akan memudahkan pelaksanaan kegiatan pembelajaran agar mencapai tujuan yang diharapkan. Selain itu, adanya rancangan program pembelajaran yang didesain dengan baik akan memudahkan pengajar dalam menyampaikan isi pembelajaran dan berpengaruh pada hasil belajar.

Perlunya mendesain program pembelajaran dengan terstruktur memiliki pengaruh yang besar terhadap hasil belajar. Berdasarkan jurnal penelitian tentang pengaruh desain pembelajaran terhadap hasil belajar sisiwa, menyatakan bahwa, Hasil pengujian hipotesis diperoleh hasil t hitung sebesar 19,005 dan nilai signifikansi sebesar o,ooo. Dengan demikian nilai $\mathrm{t}$ yang didapat lebih besar dari nilai $t$ dalam tabel $(19,005>1,7011)$, sedangkan nilai signifikansi tersebut lebih kecil dari nilai $(0,000<0,05)$. Berdasarkan hasil tersebut, maka hipotesis diterima, artinya terdapat pengaruh yang signifikan(Bahtiar, 2016: 48).
Gejala atau fenomena tersebut tergambar pada salah satu lembaga organisasi kemahasiswaan yang ada di Universitas Negeri Jakarta (UNJ) yang bergerak pada bidang pendidikan nonformal. Lembaga tersebut bernama Lembaga Semi Otonom (LSO) Qur'an Institute UNJ. Visi dari lembaga ini adalah membumikan Al-Qur'an di UNJ secara profesional untuk mewujudkan generasi Qurani. Dalam rangka mewujudkan visi tersebut, maka lembaga ini memiliki program kerja, yaitu Studi Qur'an Intensif (SQI).

Program kerja ini memiliki fokus untuk memfasilitasi mahasiswa UNJ dalam belajar tahsin Al- Qur'an. Tahsin bermakna memperbaiki atau meningkatkan kemampuan membaca Al-Qur'an. Dalam membaca AlQur'an sangat dianjurkan untuk membacanya secara tartil, memperhatikan makhraj huruf, dan hukum bacaannya. Misal, jika ada kesalahan menyebut salah satu makhraj hurufnya saja, maka akan berdampak pada salahnya arti bacaan. Pembelajaran tahsin yang ditawarkan oleh lembaga ini terdiri dari enam tingkatan, yaitu dua tingkatan pada level pra tahsin dan empat tingkatan pada tingkat tahsin.

Diasumsikan bahwa program kerja SQI perlu ditinjau ulang. Berdasarkan hasil observasi dan wawancara yang dilakukan pada bulan November 2018 di LSO Qur'an Institute UNJ ditemukan adanya beberapa gejala yang terjadi.

Pertama, belum adanya rumusan tujuan pembelajaran pada setiap tingkatan tahsin pada program SQI, sehingga belum jelas perumusan kompetensi yang diharapkan ada pada setiap tingkatan. Padahal dengan adanya Tujuan Instruksional Umum (TIU) dan Tujuan Instruksional Khusus (TIK) akan memudahkan pencapaian kompetensi yang diharapkan. Sejauh ini, baru terdapat tujuan adanya program kerja SQI secara umum.

Kedua, latar belakang pengajar, dimana tenaga pengajar SQI secara sukarela meluangkan waktunya untuk mengajar tahsin. Pengajar tahsin pada LSO QI UNJ adalah mahasiswa UNJ, baik yang berasal dari program studi (prodi) kependidikan maupun non kependidikan. Beberapa diantara pengajar tersebut merupakan lulusan program SQI, mahasiswa yang memiliki rekomendasi untuk mengajar tahsin, dan ada dua orang pengajar 
yang memang telah melakukan tes tahsin di Lembaga Qur'an Utsmani pada semester ganjil 2018.

Ketika dilakukan wawancara kepada 2 orang pengurus dan pengajar, serta 1 orang pengajar, lalu ditanyakan poin pertanyaan tentang TIU dan TIK. Mereka kebingungan untuk menjawab dan menanyakan kembali TIU dan TIK itu seperti apa. Padahal ketiga narasumber tersebut merupakan mahasiswa UNJ yang berasal dari prodi kependidikan. Masing-masing dari mereka adalah Shifa Aulia dari Prodi Pendidikan Kimia S1 selaku Mudiroh (setara dengan wakil ketua umum) LSO QI UNJ 2018 dan pengajar tahsin level 4, Anisa Ratna Pratiwi dari Prodi Pendidikan Ekonomi S1 selaku Kepala Divisi Qur'an Learning Center (QLC) 2019 dan pengajar tahsin 1, dan Nur Aulia Afriyanti dari Prodi Pendidikan Agama Islam S1 selaku pengajar tahsin 1. Hal tersebut mencerminkan bahwa kurangnya pengetahuan pengajar dalam menyusun sebuah program pembelajaran.

Ketiga, penyusunan program pembelajaran yang ada belum terstruktur. Program pembelajaran yang telah ada bernama silabus pembelajaran. Namun, pada dokumen silabus pembelajaran tersebut tidak terdapat rumusan tujuan baik TIU maupun TIK, metode pembelajarannya tidak ditulis secara jelas, dan urutan kegiatan pembelajaran dicampur pada bagian keterangan.

Padahal program pembelajaran merupakan salah satu sub sistem yang penting adanya di sebuah lembaga pendidikan. Dengan adanya penyusunan program pembelajaran yang terstruktur, maka akan mempermudah pelaksanaan pembelajaran yang lebih terarah.

Meninjau beberapa gejala di atas, maka permasalahannya cenderung pada belum adanya program pembelajaran yang terstruktur dan kurangnya pengetahuan pengajar dalam menyususun program pembelajaran. Permasalahan tersebut menyebabkan kurang jelasnya pencapaian kompetensi yang diharapkan ada pada peserta didik setelah mengikuti program SQI. Padahal adanya program pembelajaran yang terstruktur dapat berpengaruh pada pencapaian hasil belajar peserta didik.
Dalam mendesain sebuah program pembelajaran setidaknya memerlukan tahapan identifikasi atau analisis, mengembangkan, evaluasi, dan revisi. Selain itu, hendaknya perlu memperhatikan komponen pembelajaran yang terdiri dari peserta didik, tujuan, metode, dan evaluasi. Dengan begitu, adanya program pembelajaran yang terstruktur dapat memfasilitasi belajar peserta didik dan meningkatkan kinerja pengajar.

Dalam perspektif Teknologi Pendidikan terdapat kajian tersendiri terkait desain pembelajaran, di mana teknolog pembelajaran mampu mendesain pembelajaran yang mendukung proses pembelajaran, dengan mengingat latar belakang peserta dan tujuan belajar atau kompetensi (Prawiradilaga, 2014: 73). Kajian tentang desain pembelajaran memiliki peran dalam pengembangan suatu program pembelajaran yang dapat menjadi pemecahan masalah di atas.

\section{METODE}

Penelitian ini termasuk dalam jenis penelitian pengembangan (research and development). Dalam proses pengembangan, model yang digunakan adalah Model Pengembangan Instruksional (MPI) oleh Atwi Suparman. Model tersebut memiliki delapan tahapan, yaitu

1) Mengidentifikasi kebutuhan pembelajaran dan menulis tujuan pembelajaran umum. Langkah ini dilakukan secara berurut, yaitu setelah mengidentifikasi kebutuhan barulah bisa menulis tujuan. Hasil identifikasi kebutuhan pembelajaran akan digunakan dalam perumusan pengetahuan, keterampilan, dan sikap yang perlu diajarkan pada peserta didik atau tujuan pembelajaran umum.

2) Melakukan analisis pembelajaran. Analisis pembelajaran merupakan proses menjabarkan perilaku umum ke khusus yang tersusun secara logis dan sistematis.

3) Mengidentifikasi perilaku dan karakteristik awal peserta didik. Komponen ini 
digunakan untuk mengetahui perilaku dan karakteristik awal peserta didik sebelum menerima proses pembelajaran.

4) Menulis tujuan pembelajaran khusus. Tujuan Pembelajaran Khusus merupakan tujuan yang lebih khusus hasil spesifikasi dari tujuan pembelajaran umum. Dalam menyusunnya dapat menggunakan unsur ABCD, yaitu Audience, Behavior, Condition, dan Degree.

5) Menulis tes acuan patokan. Tes acuan patokan merupakan tes yang digunakan untuk menilai penguasaan terhadap materi pembelajaran. Langkah dalam menuliskan tes acuan patokan adalah menentukan maksud tes, membuat tabel spesifikasi untuk setiap tes, menulis butir tes, merakit tes, menulis petunjuk, menulis kunci jawaban, mengujicobakan tes, menganalisis hasil uji coba, dan merevisi tes.

6) Menyusun strategi pembelajaran. Atwi Suparman (2004:260) menyatakan bahwa, strategi pembelajaran yang telah dikembangkan dan digunakan pengajar sering diganti dengan istilah GBPP dan SAP. Atwi Suparman juga membagi strategi pembelajaran menjadi empat komponen utama, yaitu urutan kegiatan pembelajaran, metode, media, dan waktu.

7) Mengembangkan bahan pembelajaran. Bahan pembelajaran terdiri atas pedoman peserta didik, pedoman pengajar, naskah tes, dan bahan lainnya seperti transparansi, gambar, bagan, serta formulir isian yang dibagikan kepada peserta didik. Bahan yang dimaksud pada model ini juga mengacu pada media pembelajaran, di mana terdapat isi materi pembelajaran di dalamnya. Bahan pembelajaran digunakan sebagai pendukung untuk kebutuhan pembelajaran.

Melaksanakan evaluasi formatif. Evaluasi formatif bertujuan untuk menentukan apa yang perlu ditingkatkan atau direvisi dari produk yang telah dibuat.
Bagian metode memuat pendekatan penelitian, model dan prosedur penelitian, dan lain-nya (Wild, 1995). Pada penelitian kualitatif, bagian metode hal-hal yang ditulis antara lain pendekatan, paradigma yang digunakan, fokus penelitian, waktu, tempat penelitian, subjek/ objek penelitian, teknik penggalian data, teknik dan prinsip-prinsip peningkatan akurasi data, dan analisis. Pada penelitian kuantitatif hal-hal yang ditulis antara lain pendekatan, tempat penelitian, populasi, sampel, variabel, teknik pengambilan data, teknik pengukuran validitas data, dan teknik analisis data. Selain itu, pada penelitian kuantitatif, tidak perlu ditulis rumus statistik secara berlebihan di bagian metode.

Jika artikel yang ditulis bukan merupakan hasil riset kuantitatif dan kualitatif, terutama yang merupakan bagian dari studi kualitatif dalam jenis studi lapangan, maka bagian metode tidak perlu ditulis. Langsung saja ke bagian hasil dan pembahasan. Namun untuk jenis pendekatan kualitatif yang dirasa perlu ditulis penjelasan lebih detail, misalnya pendekatan studi genealogi, sejarah, analisis wacana, penulis dapat tetap menulis metode penelitian. Begitu juga dengan penelitian pengembangan yang harus mencantumkan model pengembangan serta alur yang diikutinya.

\section{HASIL DAN PEMBAHASAN}

Penelitian ini dilakukan dari November 2019 sampai Juni 2020. Adapun yang menjadi responden adalah 2 orang ahli desain pembelajaran dan 2 orang ahli materi dalam tahap experts review, 3 orang pengajar, serta 2 orang peserta SQI tahsin level 1 dalam tahap one to one. Berikut hasil yang diperoleh dari setiap tahap penelitian dan pengembangan :

\section{A. Mengidentifikasi Kebutuhan Pembelajaran Dan Menulis Tujuan Pembelajaran Umum}

Kegiatan identifikasi kebutuhan pembelajaran dilakukan dengan melakukan pengambilan data awal berupa :

1) Studi Dokumentasi. Dari pengambilan data tersebut ditemukan informasi dan fakta bahwa dokumen silabus pembelajaran yang 
telah digunakan hanya memiliki aspek materi serta urutan kegiatan pembelajaran, metode, alokasi waktu, dan naskah tes.

2) Wawancara. Ditemukan bahwa belum adanya perumusan tujuan pembelajaran baik khusus maupun umum, sehingga pengajar tidak memiliki tujuan yang jelas terkait hasil apa yang harus dimiliki peserta didik. Selain itu, baik pengajar maupun peserta didik mengalami kesulitan pada penyampaian materi makharijul huruf. Dari segi pengajar merasa mudah dalam mengajarkan materi tersebut, tetapi peserta didik cepat lupa dan tertukar saat praktik. Sama halnya dari segi peserta didik, mereka merasa kesulitan karena tidak ada visualisasinya.

3) Kuesioner.Pernyataan berisi tentang persentase besar teori dan praktik menurut pengajar dan peserta didik menunjukkan perbedaan. Dari segi pengajar, aspek praktik lebih dominan pada tahsin level 1. Namun, dari segi peserta didik merasa mendapatkan aspek praktik dan teori yang seimbang selama pembelajaran.

Dari hasil temuan tersebut, selanjutnya pengembang merumuskan tujuan pembelajaran umum. Tujuan pembelajaran umum yang dirumuskan tersebut, yaitu setelah mengikuti pembelajaran tahsin Al-Qur'an level 1, peserta tahsin level 1 akan dapat menggunakan materi dasar tahsin 1 dalam membaca Al-Qur'an.

\section{B. Melakukan Analisis Pembelajaran}

Hasilnya pengembang mendapati sepuluh perilaku khusus dalam tahsin AlQur'an level 1 yang disusun dalam peta kompetensi secara kombinasi.

\section{Mengidentifikasi Perilaku Dan Karakteristik Awal Peserta Didik}

Pengembang mengidentifikasi dengan cara wawancara terkait perilaku awal peserta didik dan menyebar kuesioner kecenderungan gaya belajar. Hasil yang didapati adalah perilaku awal yang dimiliki peserta tahsin level 1, yaitu sudah mengenal huruf hijaiyah dan lancar bacaannya, tetapi belum menguasai kaidah tajwid atau hukum bacaan dasar, sedangkan gaya belajar dominan cenderung pada visual dan auditori.

\section{Menulis Tujuan Pembelajaran Khusus}

Tujuan khusus ditulis berdasarkan hasil analisis pembelajaran, sehingga tahsin level 1 memiliki 10 tujuan khusus. Berikut ialah rumusan tujuan khusus :

1) Peserta tahsin level rakan dapat membedakan pelafalan makharijul huruf 1 (Al-Lisan), jika diberi kesempatan membaca huruf hijaiyah dengan minimal $75 \%$ benar.

2) Peserta tahsin level 1 akan dapat membedakan pelafalan makharijul huruf 2 (Al-Jauf, Al-Halq, Asy-Syafatain, dan AlKhaisyum), jika diberi kesempatan membaca huruf hijaiyah dengan minimal $75 \%$ benar.

3) Peserta tahsin level 1 akan dapat membedakan sifatul huruf 1 (sifat yang memiliki lawan), jika diberi kesempatan membaca huruf hijaiyah dengan minimal $75 \%$ benar.

4) Peserta tahsin level 1 akan dapat, membedakan sifatul huruf 2 (sifat yang tidak memiliki lawan, jika diberi kesempatan membaca huruf hijaiyah dengan minimal $75 \%$ benar.

5) Peserta tahsin level 1 akan dapat, mengidentifikasi panjang pendek bacaan, jika diberi kesempatan membaca ayat AlQur'an dengan minimal 75\% benar.

6) Peserta tahsin level 1 akan dapat menerapkan hukum bacaan nun sukun dan tanwin 1 (iqlab dan idzhar), jika diberi kesempatan membaca ayat Al-Qur'an dengan minimal $75 \%$ benar.

7) Peserta tahsin level 1 akan dapat menerapkan hukum bacaan nun sukun dan 
tanwin 2 (idgham bighunnah dan idgham bilaghunnah), jika diberi kesempatan membaca ayat Al-Qur'an dengan minimal $75 \%$ benar.

8) Peserta tahsin level 1 akan dapat menerapkan hukum bacaan nun sukun dan tanwin 3 (ikhfa), jika diberi kesempatan membaca ayat Al-Qur'an dengan minimal $75 \%$ benar.

9) Peserta tahsin level 1 akan dapat menerapkan hukum bacaan mim sukun 1 (idzhar syafawi), jika diberi kesempatan membaca ayat Al-Qur'an dengan minimal $75 \%$ benar.

10) Peserta tahsin level 1 akan dapat menerapkan hukum bacaan mim sukun 2 (ikhfa syafawi dan idgham mitslain), jika diberi kesempatan membaca ayat Al-Qur'an dengan minimal $75 \%$ benar.

\section{E. Menulis Tes Acuan Patokan}

Tes yang dipilih pengembang berupa latihan tilawah dan talaqqi pada setiap pertemuan dan Evaluasi Hasil Belajar (EHB) pada akhir semester. Latihan dilakukan dengan tes praktik membaca Al-Qur'an, sedangkan EHB dilakukan dengan tes lisan tanya jawab seputar teori tahsin level 1 dan praktik membaca Al-Qur'an .

\section{F. Menyusun Strategi Pembelajaran}

Pengembang melakukan penyusunan urutan kegiatan pembelajaran dengan menyusun kegiatan pendahuluan, penyajian, dan penutup, menentukan metode dan media pembelajaran, serta menentukan alokasi waktu pembelajaran dalam menit.

\section{G. Mengembangkan Bahan Pembelajaran}

Pengembang memilh jenis bahan pembelajaran konvensional, dengan menyiapkan dokumen pedoman pengajar dan peserta didik yang telah dirumuskan pada tahap sebelumnya, serta memanfaatkan media pembelajaran yang telah ada, yaitu bagan hukum bacaan dan video dari Youtube.

\section{H. Melaksanakan Evaluasi Formatif}

Pengembang melakukan evaluasi formatif dari apa yang telah dibuat pada tahap satu sampai tujuh. Evaluasi formatif yang dilakukan, yaitu experts review dan one to one. Dari hasil evaluasi formatif, maka diperoleh simpulan bahwa program pembelajaran tahsin Al-Qur'an ini layak untuk digunakan, dengan penjabaran hasil berikut ini :

Tabel 1 Hasil Experts Review

\begin{tabular}{cc}
\hline Responden & Skor Rata-Rata \\
\hline $\begin{array}{c}\text { Desain } \\
\text { Pembelajaran }\end{array}$ & 3,13 \\
Materi & 3,72 \\
Rata-Rata & 3,43 \\
\hline
\end{tabular}

Tabel 2 Hasil One to One Pengguna (Pengajar)

\begin{tabular}{cc}
\hline Responden & Skor Rata-Rata \\
\hline Nur Aulia Afriyanti & 3,34 \\
Ratih Pratiwi Putri & 3,27 \\
Siti Nurjanah & 3,00 \\
Rata-Rata & $\mathbf{3 , 2 0}$ \\
\hline
\end{tabular}

Tabel 3 Hasil One to One Pengguna (Peserta Didik)

\begin{tabular}{cc}
\hline Responden & Skor Rata-Rata \\
\hline Shafiyah Nur A. & 3,00 \\
Hanny Qisthina S. & 3,80 \\
Rata-Rata & 3,40 \\
\hline
\end{tabular}


Tabel 4 Rata-Rata Hasil One to One

\begin{tabular}{cc}
\hline Responden & Skor Rata-Rata \\
\hline Pengajar & 3,20 \\
Peserta Didik & 3,40 \\
Rata-Rata & 3,30 \\
\hline
\end{tabular}

\section{SIMPULAN}

Penelitian pengembangan ini menghasilkan dokumen program pembelajaran tahsin di LSO Qur'an Institute UNJ yang telah dikembangkan dengan baik mengacu pada tahapan MPI. Program pembelajaran ini dapat digunakan oleh pengajar SQI level 1 di LSO Qur'an Institute dalam proses pembelajaran tatap muka.

\section{UCAPAN TERIMA KASIH}

Peneliti mengucapkan terima kasih kepada Ibu Dra. Dewi Salma Prawiradilaga, M.Sc. sebagai dosen pembimbing 1 dan Ibu Dra. Suprayekti, M.Pd. sebagai dosen pembimbing 2 yang selalu bersedia meluangkan waktu untuk membimbing peneliti dalam menyelesaikan penelitian ini. Tidak lupa peneliti ucapkan terima kasih kepada semua pihak yang terlibat seperti para ahli yang sudah meluangkan waktunya untuk menilai produk ini, serta pihak LSO Qur'an Institute yang telah mengizinkan peneliti melakukan penelitian pengembangan ini dan senantiasa membantu serta memfasilitasi penulis dalam proses penyusunan penelitian ini.

\section{DAFTAR PUSTAKA}

Al-Tabany, T. I. (2014). Mendesain Model Pembelajaran Inovatif, Progresif, dan Konseptual: Konsep, Landasan, dan Implementasi pada kurikulum 2013. Jakarta: Prenada Media Group.
Ansyar, M. (2017). Kurikulum Hakikat, Fondasi, Desain, dan Pengembangan. Jakarta: Prenadamedia Group.

Bahtiar, R. S. (2016), Pengaruh Desain Pembelajaran ASSURE terhadap Hasil Belajar Siswa Sekolah Dasar. Jurnal INOVASI, XVIII, 48.

Chamisijatin, L. \& Permana, F.H. (2020). Telaah Kurikulum. Malang: UMMPress.

ETQA Administrator. (2015, August 22). Difference between a curriculum and learning programme? Retrieved November 23, 2018, from ETQA: South Africa Education Training Questions and Answer FORUM: https://www/etqa.co.za/unit-standardsskills-programmes/difference-between-acurriculum-and-a-learning-programme/

Evaluation, T. J. (1981). Standards for Evaluation of Educational Programs, Project, and Materials. New York: MC Graw-Hill Book Company.

Fadlillah, M. (2019). BermainE Permainan Anak Usia Dini. Jakarta: Prenadamedia Group.

Farida, I. (2017). Evaluasi Pembelajaran Berdasarkan Kurikulum Nasional. Bandung: Remaja Rosdakarya.

Former Member. (2017, September 26). Programs vs Curricula. Retrieved December 7, 2018, from SAP Community Wiki: https://wiki.scn.sap.com/wiki/display/SAPS F/Programs+vs+Curricula

Harahap, M. (2016). Esensi Peserta Didik dalam Perspektif Pendidikan Islam. Jurnal AlThariqah, 1, 143.

Hasanah, A. (2017). Penerapan Metode Usmani dalam Pembelajaran Al-Qur'an Santri TPQ Nurul Iman Garum Blitar. Jurnal BRILIANT, 2, 489 .

Hernawan, D. (2018). Penerapan Metode UMMI dalam Pembelajaran Al-Qur'an. PROFETIKA: Jurnal Studi Islam, 19, 28.

Hidayat, S. (2013). Pengembangan Kurikulum Baru. Bandung: Remaja Rosdakarya.

Idi, A. (2011). Pengembangan Kurikulum Teori dan Praktik. Yogyakarta: Ar-Ruzz Media.

Jateng, P. (2014, 05 1). Rencana Kegiatan Mingguan RKM TK. Retrieved 03 20, 2019, from Paud.id: www.paud.id/2014/05/rencanakegiatan-mingguan-dan-harian-rkmrkh.html

Kompri. (2017). Standardisasi Kompetensi Kepala Sekolah: Pendekatan Teori untuk Praktik Profesional. Jakarta: Prenada Media Group.

Lebih Dekat Dengan $6 T$ (Tartil.Tajwid, Tilawah, Tahfidz, Tahsin E Tadabdbur). (2016, April 28). Retrieved December 14, 2018, from KampusUndip.com: https://www.kampusundip.com/2016/05/le bih-dekat-dengan-6t-tartil-tajwid.html?m=1

Maulana, et al. (2019). Ragam Model Pembelajaran di Sekolah Dasar. Sumedang : UPI Sumedang Press. 
Mesiono. (2017). Dalam Tinjauan Evaluasi Program. Jurnal Educators: Jurnal Ilmu Pendidikan dan Kependidikan, 4, 4.

Morrison, G. R., Ross, S. M., Kalman, H. K., \& Kemp, J. E. (2011). Designing Effective Instruction: 6th edition. New York: John Wiley \& Sons, Inc.

Mudlofir, A., \& Rusdiyah, E. F. (2017). Desain Pembelajaran Inovatif. Jakarta: Rajawali Pers.

Oxford. (2019). Programme. Retrieved o1 31, 2019, from Oxford Learner's Dictionary: https://www.oxfordlearnersdictionaries.co $\mathrm{m} /$ definition/english/programme_1

Pemerintah Indonesia. (2003). Undang-Undang Nomor 20 Tahun 2003 tentang Sistem Pendidikan Nasional pasal 26, ayat 1 dan 4. Jakarta: Sekretariat Negara.

Prawiradilaga, D. S. (2012). Prinsip Disain Pembelajaran. Jakarta: Prenadamedia Group.

Prawiradilaga, D. S. (2014). Wawasan Teknologi Pendidikan. Jakarta: Prenadamedia Group.

Purnama, S. (2015, Juni 26). Huruf dalam Mendesain Media Pembelajaran. Retrieved Oktober 15, 2019, from Kompasiana:

https://www.kompasiana.com/amp/insyira/ huruf-dalam-mendesain-mediapembelajaran_55oofd33a33311bb7451299f

Republik Indonesia. (2002). Undang-Undang Republik Indonesia Nomor 18 Tahun 2002 tentang Sistem Nasional Penelitian, Pengembangan, dan Penerapan Ilmu Pengetahuan dan Teknologi pasal 1 ayat 5. Jakarta: Sekretariat Negara.

Sanjaya, W. (2011). Perencanaan dan Desain Sistem Pembelajaran. Jakarta: Prenadamedia Group.

Sasongko, A. (2017, 10 19). Mengenal Mushaf Utsmani. Retrieved o1 31, 2019, from Republika:

https://khazanah.republika.co.id/berita/du nia-islam/islam-

nusantara/oy2azk313/mengenal-mushafutsmani

Siregar, E., \& Nara, H. (2011). Teori Belajar dan Pembelajaran. Bogor: Ghalia Indonesia.

Sugiati. (2016). Implementasi Metode Sorogan pada Pembelajaran Tahsin dan Tahfidz Pondok Pesantren. Jurnal Qathruna, 3, 141.

Suparman, A. (2010). Desain Instruksional. Jakarta: Universitas Terbuka.

Suprayekti, \& Agustyarini. (2015). Analisis Peserta Didik dalam Teknologi Pendidikan. Jakarta: LPP Press UNJ.

Suwarno. (2016). Tuntunan Tahsin Al-Qur'an. Yogyakarta: Deepublish.

Tung, K. Y. (2017). Desain Instruksional: Perbandingan Model dan Implementasinya. Yogyakarta: CV. Andi Offset.
Wikipedia. (2017, December 11). Tahsin. Retrieved December 14, 2018, from Wikipedia: https://id.m.wikipedia.org/wiki/Tahsin

Wikipedia. (n.d.). Tahsin. Retrieved o1 31, 2019, from Wikipedia:

https://id.m.wikipedia.org/wiki/Tahsin

Wikipedia. (n.d.). Tajwid. Retrieved o1 31, 2019, from Wikipedia:

https://id.m.wikipedia.org/wiki/Tajwid

Wiyani, N. A. (2013). Desain Pembelajaran Pendidikan. Yogyakarta: Ar-Ruzz Media.

Yarbrough, D. B., et al. (2011). The Program Evaluation Standards : AGuide for Evaluators and Evaluation Users. California: SAGE Publications, Inc.

Yaumi, M. (2013). Prinsip-Prinsip Desain Pembelajaran. Jakarta: Prenada Media Group. 